\title{
AN ASSESSMENT OF SME'S EXPORT COMPETITIVENESS: A CASE OF KAZAKHSTAN
}

\author{
Aidana Zhaishylyk \\ Nanjing University of Science and Technology, P.R.China \\ Lifan $\mathrm{Xu}^{*}$ \\ Corresponding author: Associate professor, Nanjing University of Science and Technology, \\ P.R.China
}

\begin{abstract}
The main aim of this study is to analyze factors, which affect SME's export competitiveness in Kazakhstan. In order to achieve the aim, the survey was conducted. The numbers of respondents were 40 SMEs, which is located particularly in Almaty, Kazakhstan. Moreover, in order to testify the relationship between factors, such as firm age, firm size, innovative capacity, government support, access to finance and SME's export competitiveness, there were employed regression analyses, through using SPSS. According to above analyze, the paper put forward that government should improve taxation system for entrepreneurs, improve financial and credit regulation. Moreover, from the government side there should be assistance to the development of innovative capacity and development of infrastructure for supporting small and medium enterprises.
\end{abstract}

Keywords: small and medium enterprises, export competitiveness, government support, innovative capacity

JEL code: L250

\section{Introduction}

Small and medium enterprises (hereinafter referred to as SMEs) are backbone of any economy. The problems that SMEs are facing attracts special attention of the governments worldwide because SMEs strongly affect employment rate, substantially contribute to gross domestic product (GDP), export volume and overall health of the economy in any country. In addition, SMEs are able to respond quickly to any changes in the market situation and can help formation of the middle class. Most importantly, it creates the environment and the spirit of entrepreneurship which will help to be innovative. Kazakhstan also considers the SMEs development as one of its key success factors. As it was stated by the President of Kazakhstan, in order to increase the competitiveness of the national economy, the country has to increase competitiveness of Kazakhstani enterprises.

The government of Kazakhstan recognized that diversification of industries is required to minimize the risks resulting from its excessively resource dependent economic structure. This means industrial diversification should be realized in order to achieve sustainable, stable and long-term economic development in Kazakhstan. Furthermore, these efforts should be pursued through the expansion and diversification of the SME sector. This is because in general, SMEs play a positive role in establishing the foundation for the stability of a nation's economy, 
activating the development of the economy, expanding the export base, and advancing the industrial structure. The contribution of SMEs to Kazakhstan's economy is very limited, and SMEs in Kazakhstan are not well developed.

Therefore, this problem is one of the most relevant and hot issues not only in the business world, but also in the scientific, political communities of contemporary Kazakhstan. High competitive Kazakhstani enterprises are the key to the success of Kazakhstan.

Thus, this paper aims to assess the factors which will affect export competitiveness of SME using internal and external factors, which obtained by survey conducted. Regression analyses were applied to investigate the relationships between factors and SME export competitiveness. The result indicates that export competitiveness of SME is affected by firm age and government support. The second part of section is discussed about factors affecting the export competitiveness of SMEs within the context of literature review. In section 3 the methodology part will be illustrated. In methodology part is mainly consisted of analyses and data, which will be evaluated by SPSS. In section 4, basic finding will be reported and finally, section 5 will conclude and put forward some recommendation for policy makers.

\section{Literature review}

Over the last decades, there were different variables used in the literature, in order to analyze the factors which will assess export potential of firms. In spite widespread acceptance of its importance of concept "competitiveness", there is still some gaps for future research of this term. Michael E. Porter (1998), the professor of Harvard Business School, considered as one of the most cited authors of this research area. According Porter, competitiveness stems from value creating strategy by a company. Value here is determined as the price the customer is eager to pay. The author divides the competitive advantage mainly by two types: cost leadership and differentiation.

It is not obvious whether firm age and firm size impact firm's capability to be fruitful at exploration or exploitation. According to Voulgaris F. and Papadogonas T. (2006), their empirical studies show that firm age and firm size are key driver factors of firm competitiveness. However, according to Loderer and Waelchli (2010), they emphasize the older firm's disadvantages, because they often develop stiffer, bureaucratic structures and can create a "competency trap" where past successes and technological areas of expertise create inertial pressures that prevent them from exploring new technological domains.

According to Appiah K., Selassie H. and Burnley R. (2015), their research find out that there is no relationship between innovative capacity and SME's export competitiveness. Kazakhstani scientists, such Radosevic and Myrzakhmet (2009) also discuss the factors that have impact on innovative capacity and activity of the SME. However, a majority of scientific issues that are related to sufficient state management of innovative capacity within the economy remain unclear. According to Eniola A.A. and Entebangn H. (2015), they find out relationship between government policy and firm performance of SME. Likewise, government support has a major impact on the competitiveness of SMEs. Conceptually, the research work indicates that SME firm performance differs with the choice of the government policy which they approved. 
Dandago, K. I., and Usman, A. Y. (2015) indicate that government support and their incentives support systems for SMEs play an essential role. Many suggestions and recommendations have appeared from the researchers and there is still need strong efforts of governments, through its different kind of efficient policies affecting competitive environment in the market, which lead to fruitful and profitable operations of SMEs. These recommendations are following: to invite government to take concrete actions to eliminate dumping, smuggling and importation of cheap foreign products; reducing corruption actions; providing social justice; providing market information; developing the infrastructure; providing training for SMEs and encouraging private investment. Shortage of access to external and internal financing can be as a major challenge to the growth of SMEs, and it has accounted for high rates of failure among those SMEs.

According to Shah et al. (2013), financial institutions behave more cautiously when providing loans to SMEs. In their research, they discuss that SMEs are usually charged comparatively high interest, high collateral and loan guarantees. Krasniqi, B. A. (2007) finds that loan policies and collateral requirements discourage firms from obtaining loans from banks. According to Ayyagari et al. (2006) show that political instability, public issues and financing directly affect the rate of growth of small firms, with financing being the most significant constraint affecting growth of small firms. Rocha et al. (2011) evaluate the most essential constraint on firm growth in emerging countries: they find that each country crosses a different set of constraints and that these constraints also differentiated by firm features, especially firm size.

\section{Empirical analyses}

\subsection{Overview about SMEs in Kazakhstan}

SMEs play a positive role in establishing the foundation for the stability of a national economy, activating the development of the economy, expanding the export base, and advancing the industrial structure. Moreover, SMEs have played a fundamental role in the evolution of the economies of developed countries. However, the SME sector is not fast grown sector in Kazakhstan. The highest number of active SMEs operates in Almaty $(127,900)$ and South Kazakhstan123,900) region. While lowest number of active SMEs operates in North Kazakhstan region. 


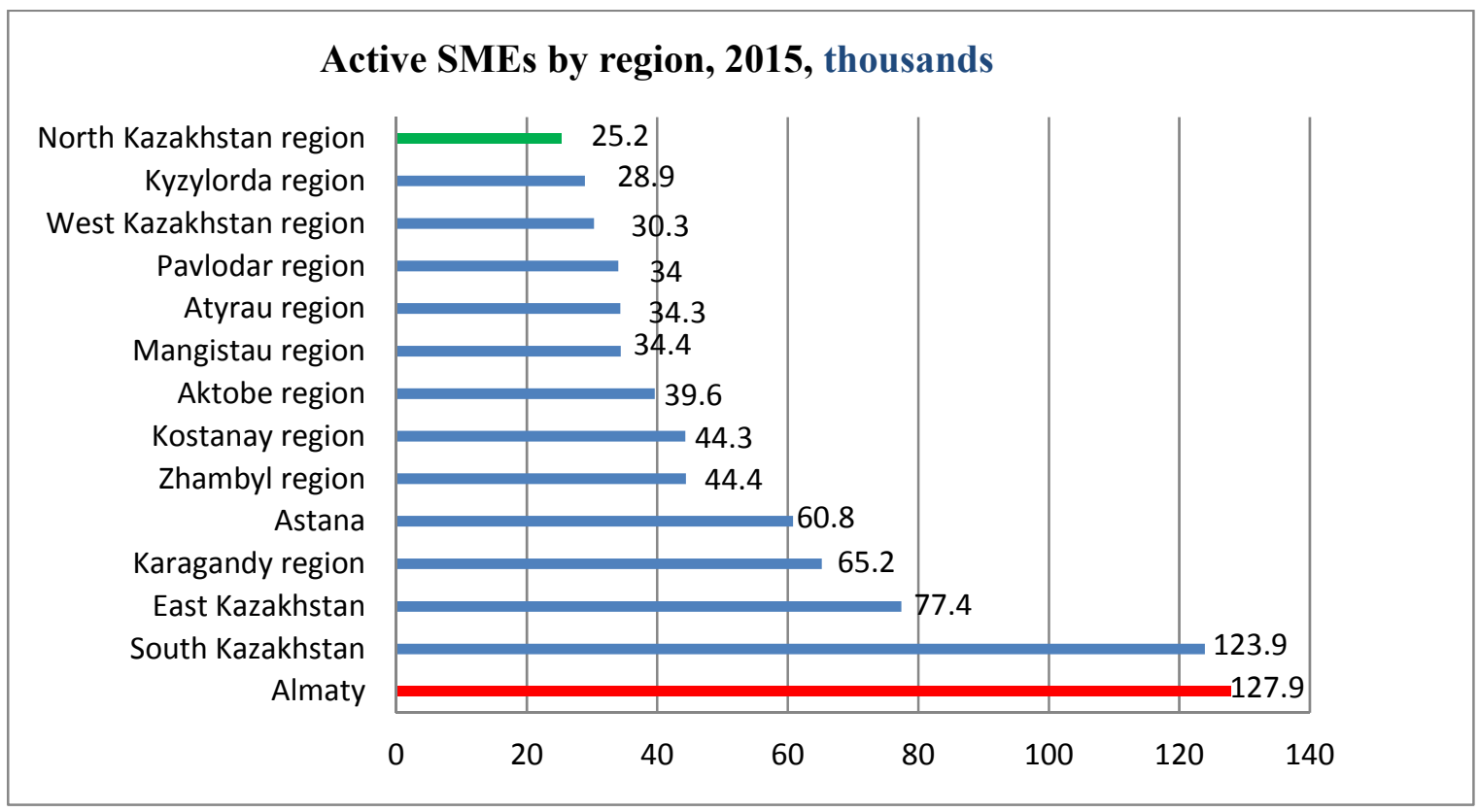

Fig. 1 Source :www.stat.gov.kz

This why, I choose Almaty as target of my research, as there are biggest number of active SMEs. Next paragraph will be related to Almaty's SME and its condition.

Almaty used to be the capital of Kazakhstan between 1929 and 1997, and today it is the city of national significance. As of January 1, 2015, Almaty had a population of $1,548,300$ people or $8.8 \%$ of Kazakhstan's population (third place among the regions and cities of national significance). The city's economically active population was 811,000 people or $8.9 \%$ of the country's total, with 766,400 people having jobs.

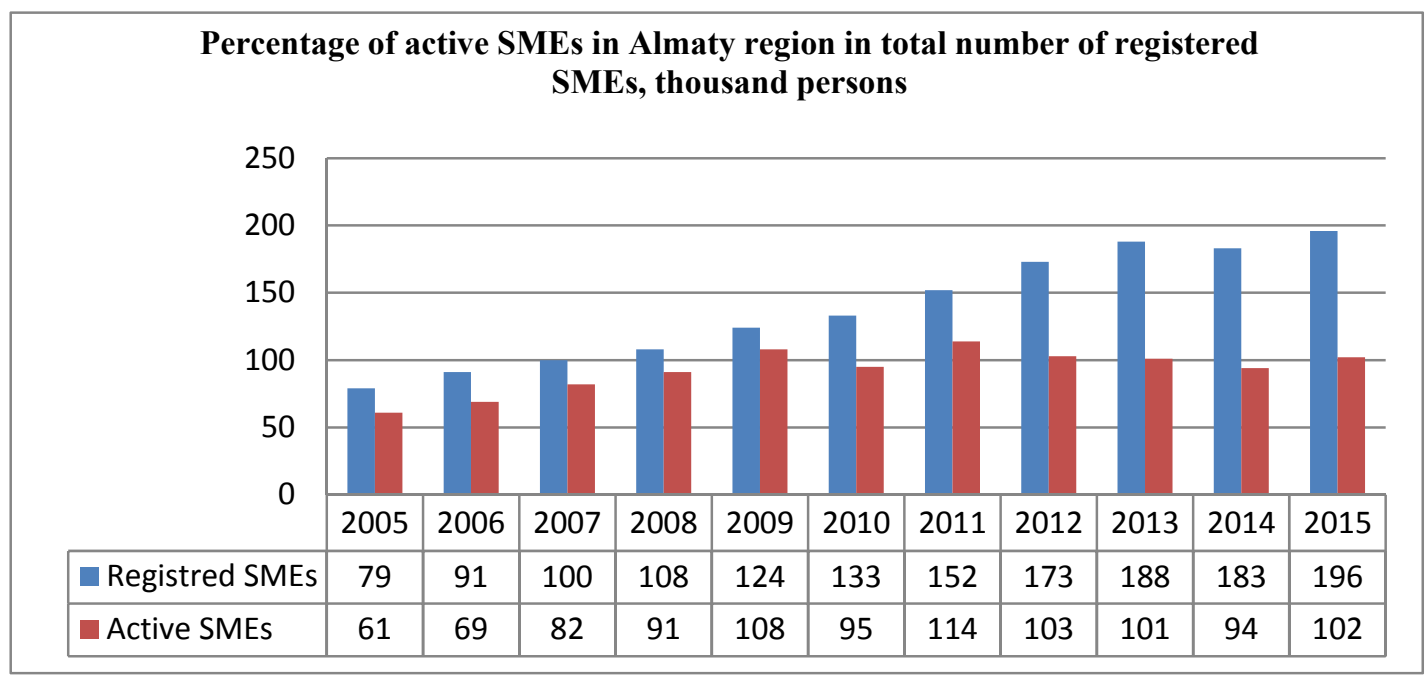

Fig. 2 Source: www.stat.gov.kz 
The number of registered and active SMEs in Almaty tends to grow. By the end of 2015, the number of registered and active SMEs increased by 2.6 times compared to 2005 . The number of active SMEs increased considerably in 2011 and 2013 (average annual growth of 36\%), showing a moderate growth of $3.9 \%$ in 2015 .

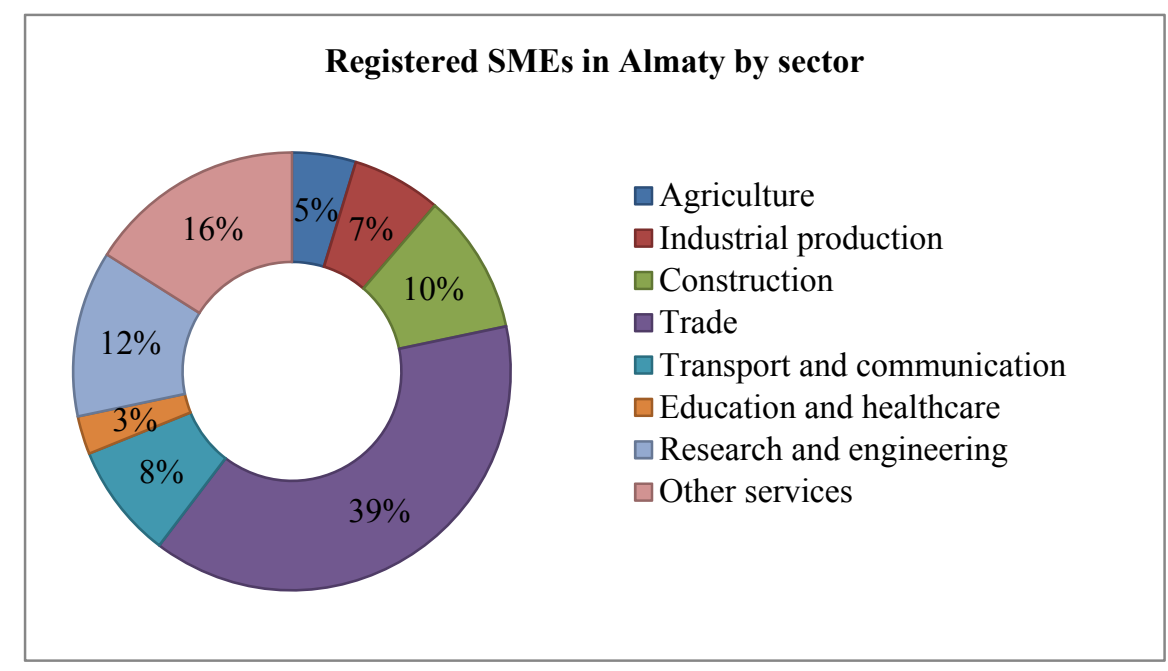

Fig. 3 Source: www.stat.gov.kz

The majority of SMEs in Almaty are active in trade and services. Trade accounts for $39 \%$ of all SMEs. Second largest percentages are shown by construction and research and engineering, where $10 \%$ and $12 \%$, respectively. Transport and communication account for $8 \%$. Agriculture and industrial production share the least percentage among all sectors.

\subsection{Data Collection and Research Methodology}

In order to achieve the research purpose, data were collected from 40 SMEs exporters. In our research, we have focused only one region of Kazakhstan, which is Almaty region, because the majority active SMEs exporters are located in this region.

The questionnaire was composed of three sections. In the first section, there was gathered general information about firms, such as the number of employees, how long the company running its business, last five years sales, imports, exports, and research and development expenditure. Section two was particularly about export activities. In the third section gathered external and internal resources, the firm's innovative capacity, government support and financing. Questions were evaluated through using Likert scale from 1 to 5 .

\subsection{Research Framework}

$\mathrm{EC}=\beta_{0}+\beta_{1} F A+\beta_{2} F S++\beta_{3} I N V++\beta_{4} G S+\beta_{5} F I N+\mu$ 


\section{Dependent Variable Independent Variable}

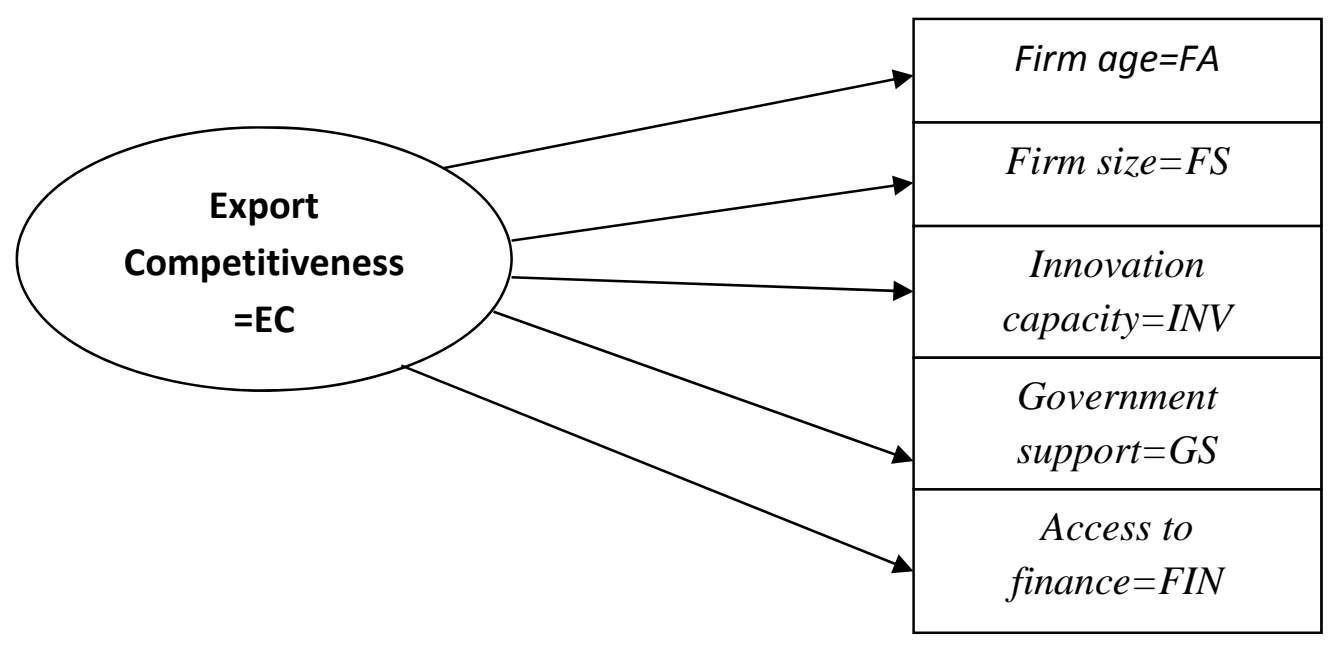

Fig. 4 The research framework

\subsection{Research Hypothesis}

H1: There is significant positive relationship between firm age and SME export competitiveness.

$\mathrm{H} 2$ : There is significant positive relationship between firm size and SME export competitiveness.

H3: There is significant positive relationship between innovative capacity and SME export competitiveness.

H4: There is significant positive relationship between government support and SME export competitiveness.

H5: There is significant positive relationship between access to finance and SME export competitiveness.

\subsubsection{Results and findings}

In order to be sure that our questions are appropriate and reliable, we calculated the Cronbach's Alpha values, by using SPSS statistical package. According to theories, if $\alpha$ value is 0.70 or above is sufficient for the reliability of questions. Below shows the table where was calculated the Cronbah's Alpha that closely connected to question sets. In the Table1, the $\alpha$ value is showed from 0.701 to 0.837 , which means questionnaire has satisfactory value, and appropriate. 
Table 1. Cronbach's Alpha

\begin{tabular}{|l|l|l|}
\hline \multicolumn{1}{|c|}{ Variables } & Cronbach's Alpha (a) & N (number respondents) \\
\hline Export Competitiveness (EC) & 0.837 & 40 \\
\hline Firm age (FA) & 0.750 & 40 \\
\hline Firm Size (FS) & 0.739 & 40 \\
\hline Innovative capacity (INV) & 0.715 & 40 \\
\hline Government support (GS) & 0.701 & 40 \\
\hline Access to finance (FIN) & 0.723 & 40 \\
\hline
\end{tabular}

Source: SPSS

Table 2. Innovative capacity

\begin{tabular}{|c|c|c|c|c|c|}
\hline Innovative capacity & $\mathbf{N}$ & Min & Max & Mean & Sd \\
\hline Access to $\mathrm{R} \& \mathrm{D}$ unit & 40 & 1 & 4 & 2.081 & 1.032 \\
\hline Specialized staff for R\&D & 40 & 1 & 4 & 1.763 & 0.094 \\
\hline Research findings & 40 & 1 & 3 & 1.246 & 0.632 \\
\hline $\begin{array}{l}\text { Training of R\&D } \\
\text { specialized staff }\end{array}$ & 40 & 1 & 5 & 1.633 & 0.083 \\
\hline $\begin{array}{l}\text { Cooperation with research } \\
\text { centers and other } \\
\text { institutions are highly } \\
\text { devoted }\end{array}$ & 40 & 1 & 5 & 2.872 & 1.252 \\
\hline
\end{tabular}

Source: SPSS

Table 2 corresponds an innovative capacity for its competitiveness by respondent's company. The innovative capacity highest mean value $(2.872)$ was Cooperation with research center and other institution while the lowest mean value (1.246) was research findings.

Table 3. Access to finance

\begin{tabular}{|l|l|l|l|l|l|}
\hline $\begin{array}{c}\text { Access to } \\
\text { finance }\end{array}$ & N & Min & Max & Mean & Sd \\
\hline Bank loans & 40 & 1 & 4 & 1.373 & 0.627 \\
\hline $\begin{array}{l}\text { Financial } \\
\text { leasing }\end{array}$ & 40 & 1 & 3 & 1.061 & 0.315 \\
\hline $\begin{array}{l}\text { Owners self- } \\
\text { finance }\end{array}$ & 40 & 1 & 5 & 4.574 & 1.023 \\
\hline Venture capital & 40 & 1 & 3 & 1.263 & 0.781 \\
\hline $\begin{array}{l}\text { Government } \\
\text { funding }\end{array}$ & 40 & 1 & 4 & 1.891 & 1.092 \\
\hline
\end{tabular}

Source: SPSS

In Table 3 shows the questionnaire results about access to finance, where respondents were asked to rate the item on scale from (1) hardly ever to (5) almost always. As it is seen, majority number 
of SMEs spent its own funding for their business. This is marked by the highest mean value of 4.574. While financial leasing indicates the lowest mean value, which is 1.061 .

Table 4. Government support

\begin{tabular}{|l|l|l|l|l|l|}
\hline $\begin{array}{l}\text { Government } \\
\text { support }\end{array}$ & N & Min & Max & Mean & Sd \\
\hline $\begin{array}{l}\text { Support from } \\
\text { Export } \\
\text { association }\end{array}$ & 40 & 1 & 4 & 2.681 & 0.852 \\
\hline $\begin{array}{l}\text { Consulting } \\
\text { from } \\
\text { government } \\
\text { centers }\end{array}$ & 40 & 1 & 5 & 3.153 & 1.124 \\
\hline $\begin{array}{l}\text { Sourcing } \\
\text { export } \\
\text { finance }\end{array}$ & 40 & 1 & 3 & 1.254 & 0.561 \\
\hline $\begin{array}{l}\text { Export trade } \\
\text { information }\end{array}$ & 40 & 1 & 4 & 1.312 & 0.673 \\
\hline $\begin{array}{l}\text { Easing } \\
\text { taxation }\end{array}$ & 40 & 1 & 3 & 1.424 & 0.798 \\
\hline
\end{tabular}

Source: SPSS

Table 4 indicates the questionnaire result about government support, where SMEs were asked to rate the usefulness of government support on a scale from (1) not useful, to 5 very useful. The highest mean value in government support is consulting from government center, where mean value is 3.153. The second highest mean value is receiving easing taxation (mean value 1.424). The lowest mean value is sourcing export finance (mean value 1.254).

Table 5. Correlation matrix

\begin{tabular}{|l|l|l|l|l|l|l|l|l|}
\hline Variables & Mean & $\begin{array}{l}\text { Standard } \\
\text { deviation }\end{array}$ & EC & FA & FS & INV & GS & FIN \\
\hline EC & 3.258 & 0.754 & 1 & $0.067^{*}$ & $-0.259^{* *}$ & -0.038 & 0.133 & -0.589 \\
\hline FA & 2.408 & 0.675 & $0.067^{*}$ & 1 & $0.377^{* *}$ & -0.125 & -0.452 & -0.356 \\
\hline FS & 2.689 & 0.687 & $-0.259^{* *}$ & $0.377^{* *}$ & 1 & -0.784 & -0.235 & 0.0127 \\
\hline INV & 1.919 & 0.618 & -0.038 & -0.125 & -0.784 & 1 & -0.196 & 0.105 \\
\hline GS & 1.964 & 0.801 & 0.133 & -0.452 & -0.235 & -0.196 & 1 & 0.0125 \\
\hline FIN & 2.027 & 0.767 & -0.589 & -0.356 & 0.0127 & 0.105 & 0.0125 & 1 \\
\hline
\end{tabular}

**.Correlation is significant at the 0.01 level (two tailed)

*.Correlation is significant at the 0.05 level (two tailed)

$$
\text { Source: SPSS }
$$

Correlation matrix was used in order to find out the relationship between the variables. As in table indicates that firm age and government support positively effect on export competitiveness while other variables showed negative sign, which means these variables are not strongly effect on export competitiveness. 
Table 6. Model summary

\begin{tabular}{|c|c|c|c|c|}
\hline Model & R & R Square & $\begin{array}{c}\text { Adjusted R } \\
\text { Square }\end{array}$ & $\begin{array}{c}\text { Std. Error of the } \\
\text { Estimate }\end{array}$ \\
\hline FA & $0,209^{\text {a }}$ & 0,044 & 0,021 & 1,05678 \\
\hline FS & $0,169^{\text {a }}$ & 0,012 & $-0,097$ & 1,27860 \\
\hline INV & $0,105^{\text {a }}$ & 0,006 & $-0,095$ & 1.02568 \\
\hline GS & $0,225^{\text {a }}$ & 0,090 & 0,056 & 1,05678 \\
\hline FIN & $0,108^{\text {a }}$ & 0,024 & $-0,085$ & 1,035784 \\
\hline \multicolumn{7}{|c|}{ a. Predictors: (Constant), FA,FS,INV,GS,FIN } \\
\hline
\end{tabular}

Source: SPSS

Based on the table, firm age result and government support are shown the $R^{2}$ for FA is 0.044 , while $R^{2}$ for GS is 0.090 , which interprets that approximately $4,4 \%$ of firm age and $9 \%$ government support affect on the SME export competitiveness.

Table 7. Coefficient table

\begin{tabular}{|c|c|c|c|c|c|c|}
\hline \multicolumn{7}{|c|}{ Coefficients $^{\mathrm{a}}$} \\
\hline \multirow{2}{*}{\multicolumn{2}{|c|}{ Model }} & \multicolumn{2}{|c|}{ Unstandardized Coefficients } & $\begin{array}{l}\text { Standardized } \\
\text { Coefficients }\end{array}$ & \multirow[t]{2}{*}{$\mathrm{t}$} & \multirow[t]{2}{*}{ Sig. } \\
\hline & & $\mathrm{B}$ & Std. Error & Beta & & \\
\hline \multirow{6}{*}{1} & (Constant) & 2,141 & 0,835 & & 2,564 & 0,000 \\
\hline & FA & 0,008 & 0,188 & 0,007 & 2.678 & $0,003 *$ \\
\hline & $\mathrm{FS}$ & $-0,041$ & 0,172 & $-0,044$ & $-0,237$ & 0,814 \\
\hline & INV & $-0,038$ & 0,160 & $-0,042$ & $-0,238$ & 0,813 \\
\hline & GS & 0,180 & 0,150 & 0,215 & 3.045 & $0,020^{*}$ \\
\hline & FIN & $-0,009$ & 0,189 & $-0,037$ & $-0,046$ & 0,963 \\
\hline \multicolumn{7}{|c|}{$\begin{array}{l}\text { a. Dependent Variable: EC } \\
\text { Correlation is significant* }(p=<0.05)\end{array}$} \\
\hline
\end{tabular}

Source: SPSS

Based on coefficient table, it says that FA and GS B $=0.007$ and $\mathrm{B}=0.215$, respectively, and these variables are significant at 0.003 and 0.020 ( $\mathrm{p}$ value is less than 0.05 ), which we can accept $\mathrm{H} 1$ and H4. Other hypotheses rejected ( $\mathrm{H} 2, \mathrm{H} 3, \mathrm{H} 5)$, because their Beta coefficients are all negative sign and they don't show significance of variable as their $p$ values are higher than 0.05 . 
Table 8 . Overall result of hypothesis

\begin{tabular}{ll}
\hline \multicolumn{1}{c}{ Hypothesis } & Result \\
\hline $\begin{array}{l}\text { H1: There is significant positive relationship between firm age and SME } \\
\text { export competitiveness }\end{array}$ & Accepted \\
$\begin{array}{l}\text { H2: There is significant positive relationship between firm size and SME } \\
\text { export competitiveness }\end{array}$ & Rejected \\
$\begin{array}{l}\text { H3: There is significant positive relationship between innovative capacity } \\
\text { and SME export competitiveness }\end{array}$ & Rejected \\
$\begin{array}{l}\text { H4: There is significant positive relationship between government support } \\
\text { and SME export competitiveness }\end{array}$ & Accepted \\
$\begin{array}{l}\text { H5: There is significant positive relationship between access to finance and } \\
\text { SME export competitiveness }\end{array}$ & Rejected \\
\hline
\end{tabular}

\section{Conclusion and recommendation}

Based on findings of this paper, the relation between the firm age, firm size, innovative capacity, government support and access to finance and SME's export competitiveness is examined via regression analyses. The result indicates that there is a positive relation between firm age, government support and export competitiveness of SMEs. On the other hand, negative relationship was founded between the firm's size, innovative capacity, access to finance and export competitiveness of SMEs. According to regression analysis, FA and GS indicated showed positive sign, which we can accept $\mathrm{H} 1$ and H4. This means that, firm age and government support can influence significantly to the export competitiveness of SMEs, because older experienced firms showed higher export competitiveness than younger firms. Also, government support positively influence to the firm performance, especially their export competitiveness. Other hypotheses rejected $(\mathrm{H} 2, \mathrm{H} 3, \mathrm{H} 5)$, because their Beta coefficients are all negative sign and they don't show significance of variable as their $\mathrm{p}$ values are higher than 0.05 .

As a result, the importance of being export competitive of SMEs under globalized world is an undeniable fact. Moreover, no doubt it is difficult for SMEs to compete the revivals in global market. SMEs should implement different efficient strategies, in order to be competitive overseas market. According to developed country, where SMEs export competitiveness is higher, government support plays essential role. Our finding also shows the significant relation between government support and export competitiveness of SMEs. Following countermeasures should be done in order to improve the export competitiveness of SME and government policy makers should assist for completely implementation.

1. Improvement of economic relations of SMEs in production with the purpose of ensuring their competitiveness in the global market.

2. Both state and market price regulation on products of small and medium size businesses with the goal to raise demand among the population and increase competitiveness of local businesses both on the domestic and foreign markets. 
3. Implementation of the guaranteed minimum prices system, which can provide the sufficient level of profitability for small businesses.

4. Tax concession exemption for small businesses, which invest in the priority industries or are committed to the sustainable development principle observing ecological standards.

5. Development of infrastructure for supporting small and medium-sized enterprises.

6. Assistance in the development of innovative small and medium-sized businesses, including in scientific and technical activities.

7. Assistance to exporting companies and export-oriented enterprises of the republic in entering the foreign market and conducting foreign economic activity.

8. Expansion of the availability of bank loans for small and medium-sized businesses (interest rate subsidies).

9. From observation there is poor infrastructure which is hindering the development of SMEs. This is why; government should take account in its policy improvement of infrastructure.

10. Also, SMEs are facing lack of innovative strategy in their development. Every SME should develop their research and development and improve their marketing skills.

\section{References}

Appiah K., Selassie H. and Burnley R. (2015) "Determinants of SME international competitiveness: a case of Ghanain horticultural exporters", The Business and Management Review, 6(3), 192-204.

Ayyagari., Meghana and Vojislav Maksimovic (2006) "How Important Are Financing Constraints? The Role of Finance in the Business Environment”, World Bank Policy Research Working Paper, No. 3820.

Dandago, K. I., and Usman, A. Y. (2015) “Assessment of government industrialization policies on promoting the growth of small scale industries in Nigeria", Proceedings from Ben-Africa Conference Zanzibar.

Eniola, A.A. and Entebang, H. (2015) "Government policy and performance of Small and Medium Business Management”, International Journal of Academic in Business and Social Sciences, 5(2), 239-248.

Information on http://www.stat.gov.kz

Krasniqi, B. A., (2007) " Barriers to entrepreneurship and SME growth in transition: The case of Kosova”, Journal of Developmental Entrepreneurship, 12(1), 71-94. 
Loderer, C. \& Waelchli, U. (2010) "Protecting minority shareholders: Listed versus unlisted firms", Financial Management, 39, 33-57.

Porter M. E. (1998) “Competitive advantage creating and sustaining superior performance”, The Free Press, New York.

Radosevic, S. and Myrzakhmet, M. (2009) "Between vision and reality: Promoting innovation through technoparks in an emerging economy". Technovation, 29(10), 645-656.

Rocha R., Farazi S., Khouri R., \& Pearce D., (2011) “The status of bank lending to SMEs in the Middle East and North Africa Region: Results of a joint survey of the Union of Arab Banks and the World Bank”, Policy Research Working Paper 5607.

Shah, S.F.H., Nazir, T., Zaman, K., \& Shabir, M. (2013) "Factors affecting the growth of enterprises: A survey of the literature from the perspective of small- and medium-sized enterprises", Journal of Enterprise Transformation, (3), 53-75.

Voulgaris F. \& Papadogonas T. (2006) "Financial factors affecting profitability and employment growth: the case of Greek manufacturing”, International Journal of Financial Services Management, 2(3), 232-242. 